Canadian Journal of Family and Youth, 6(1), 2014, pp 29-57

ISSN 1718-9748 (C) University of Alberta

http://ejournals.library.ualberta.ca/index/php/cjfy

\title{
Dual-Career Couples in Bangladesh: Exploring the Challenges
}

\author{
Nahneen Sultana, Ayesha Tabassum, and Abu Md. Abdullah
}

\begin{abstract}
With the increased opportunity of women's education and employment, the numbers of dualcareer couples are increasing in Dhaka, the capital city of Bangladesh. As a result, these couples are confronting various types of problems every day, as they need to maintain both the work and family role demands simultaneously. After an extensive literature review, the study was initiated to explore the challenges of dual-career couples in terms of Dhaka, Bangladesh. A structured questionnaire was used as a means of data collection and the survey was conducted on 155 dual-career couples $(\mathrm{N}=310)$ in Dhaka. Principle component analysis revealed nine challenges that are encountered by dual-career couples. These challenges include childcare, family-work conflicts, work-family conflicts, marital relations, dependency on others for housekeeping and childcare, personal well-being, family activity maintenance, housekeeping, and social relationship maintenance.
\end{abstract}

Nahneen Sultana is serving as a Senior Lecturer with the Faculty of Business Administration in Eastern University Bangladesh. Her research interest is in mainly Human Resource Management aspects, Business Communication and Entrepreneurship. You may contact her at urmee97@yahoo.com. Ayesha Tabassum is currently working as an Assistant Professor at Eastern University. She had her MBA in HRM and Marketing from North South University. Her area of research interests are quality of work life, work-family balance, human resources management practices, service quality, and the higher education sector. Abu Md. Abdullah is presently working as an Assistant Professor at Eastern University. He did MBA in Strategic \& International Management from the University of Dhaka. His area of research interests are human resources management practices, environmental protection, and interpersonal communication in the workplace. He is available at abdullah.du@gmail.com. 
Sultana, Tabassum, \& Abdullah

\section{Introduction}

In recent years, researchers have focused on the phenomenon of dual-career couples, where two working people are committed to a relationship. These types of couples are integrating both their family and work life. Past studies have already posited that the numbers of such couples are increasing, primarily due to the increased participation of women in professional employment (Gorissen, 2009; King, 2005). Female participation in the workforce has been easier due to their greater access to education and job market (Smith, 1992). This trend has radically changed traditional family structures and gender roles (Gorissen, 2009), where the male is considered the wage earner and the female is the housekeeper. As the numbers of dual-career couples have increased, this traditional family form has been declining (Elloy \& Smith, 2003).

The dual-career phenomenon has received noteworthy research attention since the pioneering studies conducted by Rapoport and Rapoport in 1976. These scholars have defined dual-career couples as a specific type of dual-worker family in which both members follow a professional career while at the same time maintain a family life together (Rapoport \& Rapoport, 1976). The introduction of such couples occurred due to the necessity of earning a family income, thus the motivation for work is primarily monetary rewards (Gorissen, 2009). Despite financial benefits, dual-career couples are facing several challenges (Dribe \& Stanfors 2010; Neault \& Pickerell 2005). The most frequently cited problems by dual-career couples are work-family conflict (Greenhaus \& Beutell, 1985; Duxbury \& Higgins, 2003), division of labour for household activities (Yogev \& Brett, 1985; Coltrane, 2000), childcare (Crouter \& Manke, 1997; Neault \& Pickerell 2005), marital problems (Duxbury \& Higgins, 1991; Yogev \& Brett, 1985), career advancement (Arbeau, 2001; Neault \& Pickerell, 2005), and physical and psychological health (Floderus, Hagman, Aronsson, Marklund, \& Wikman, 2009; Lindfors, Berntsson, \& Lundberg, 2006). Usually these problems arise due to changes 


\section{Dual-Career Couples}

in the stereotypical role behaviors accorded to traditional family role theory. As female participation and movement has augmented dual-career couples, the female need to maintain the work, household, and childcare responsibilities together, creates work and family role strain (King, 2005). Moreover, the concept of the division of household labour has also changed in terms of such employed couples. Currently, males are also sharing household and childcare responsibilities, which puts additional pressure on the male members of dual-career families to balance work and family roles. An obvious outcome of such strain and conflict is greater dissatisfaction with marriage, career, and life.

Such a worldwide phenomenon has also changed the roles of Bangladeshi family networks (Khan, 2004). Though Bangladesh is a country where motherhood is considered as the most desirable role for women and marriage is considered the goal of every woman's life, the concept of women's independence and autonomy is changing (Khan, 2004). As a result, women are becoming more educated and obtaining the opportunity to participate in the country's workforce. Thus, the roles of women are expanding in terms of both family and beyond the family in workplaces. Women are acquiring more opportunities to contribute, not only to family earnings but also to the economy of the country. Based on this scenario, the current study focuses on exploring the challenges faced by dual-career couples in Bangladesh. Data was collected from dual-career couples of various professions by using a structured questionnaire survey. The study also included a literature review on the difficulties encountered by dual-career couples and factor analysis of the data confirmed the factors that were seen as challenges in couple's lives.

\section{Dual-Career Couples}

Industrialized society underwent a remarkable change during the last quarter of the twentieth century particularly with regard to the roles of men and women in the labor-force and, to a lesser extent, in the home (Roehling \& Moen, 2003). This change was due to the 
Sultana, Tabassum, \& Abdullah

women's movement, which successfully advocated for the equal opportunity of women in the workplace (Friedan, 1963). This movement was a result of expanded educational opportunities for women and increasing job opportunities for educated and aspiring women (Hester \& Dickerson, 1984). Moreover, the steady decline in the earning power of men's wages has made women's employment a necessity for many families (Wilkie, 1991).

As previously mentioned, the term 'dual-career couple' was defined as one in which both heads of household pursue careers and at the same time maintain a family life together (Rapoport \& Rapoport, 1969). Some studies have differentiated between dual-career and dual-worker families. According to Aldous (1982), the dual-worker terminology implies that women's unpaid work in the household is not 'genuine' work. Gorrisen (2009) mentioned different types of dual-career couples identified by Rapoport and Rapoport (1971) and Hall and Hall (1980). According to Rapoport and Rapoport (1971) there are four types of dualcareer families: familistic, careerist, conventional and coordinate. The major difference between familistic and careerist couples is that familistic couples are most active in the household sphere, whereas careerist couples are more concerned about occupational advancement. Traditional family roles prevail in conventional families, where the female sacrifices her career in favour of the man. The coordinate type of family is characterized by a careerist male who is willing to participate in the household activities and a familistic female with career aspirations (Rapoport \& Rapoport, 1971).

Hall and Hall (1980) also identified four general types of dual-career couples based on high or low involvement with family and career issues: accommodators, adversaries, allies and acrobats. In case of the accommodator couple, one member is particularly high in career involvement and low in household involvement. Adversaries are highly involved with their career and hardly involved with household responsibilities while allies are either very involved with their career or with their household roles, but not with both functions at the 


\section{Dual-Career Couples}

same time. Finally, a family where both partners are exceptionally involved in all their roles are known as acrobats (Gorissen, 2009).

Both partners of dual-career couples may benefit from the status of 'dual-career,' apart from the difficulties encountered. One major advantage for such a family is an increased standard of living (Green \& Zenisek, 1983) due to the greater family income through a double pay-cheque (Gorissen, 2009). This may substantially provide job flexibility, new educational opportunities, and career change possibilities for both the partners (Gorissen, 2009). In addition, the household activity restriction found within traditional family structures change (Gorissen, 2009) as the male becomes actively involved in household and childcare activities (Russell, 1986). Moreover, married women can have greater opportunity for participation in social networks through work (Green \& Zenisek, 1983) which may ensure personal growth (Hall \& Hall, 1979) and enhance the well-being of the women (Baruch, Barnett \& Rivers, 1983). ${ }^{1}$

\section{Dual-Career Challenges ${ }^{2}$}

Lee (1980) posited that dual-career couples face too many problems as they need to play too many roles with too many demands on time and energy. Dual-career couples find it a constant juggling act to combine both work and family demands (Gorissen, 2009), and thus experience work-family conflict; a conflict in the relationship between work and family roles (Edwards \& Rothbard, 2000; Greenhaus \& Beutell, 1985). This type of conflict occurs when the demands imposed by one role becomes incompatible with another (Duxbury \& Higgins,

\footnotetext{
1 With Bangladesh being conservative and Isalimi Shariah being the constitution, homosexual relationships are not approved and accepted. So only heterosexual couples are included in the study for identifying the challenges of Dual Career Couples. Here, selected dual career couples are salaried and involved in the workplace; not staying home.

2 It should be noted that the heritage of Bangladeshi culture involves family bonding, strong children orientation, and a high level of involvement with relatives and friends. The society of Bangladesh expects women to take care of the family and children.
} 
Sultana, Tabassum, \& Abdullah

2003). Though it is found that wives normally face higher levels of work-family conflict than husbands among the dual career family (Higgins, Duxbury, Lee, \& Mills, 1994; Marshall \& Barnett, 1993), dual-career men may also experience negative spillover from the work domain (Higgins \& Duxbury, 1992). Galinsky, Bond, and Friedman (1996) found in their study on dual-career couples that $42 \%$ of non-parents and $58 \%$ of parents reported workfamily conflicts. Along with this type of conflict, some couples may face family-work conflict as a result of family-to-work negative spillover (Frone, Russell, \& Cooper, 1992). For example, a disagreement between spouses may lead to poor job performance (Roehling, Moen, \& Batt, 2003).

Dual-career couples also confront day-to-day challenges regarding household activity management (Anderson \& Spruill, 1993). Household activities such as shopping, cooking, cleaning, and doing laundry are mostly carried out by the women in a family. However, in dual-career families, females have less time to do these necessary activities related to the household (Neault \& Pickerell, 2005). This problem is usually encountered when males only involve themselves in one-third of the family work (Pleck, 1977). Thus, the division of household responsibilities among the dual-career couples is a serious concern (Yogev, 1983), as both husband and wife has the tendency to compare their household workloads with those of other wives and husbands (Thompson, 1991).

Besides housekeeping activities, dual-career men and women find it challenging to balance career and parenthood (O'Laughlin \& Bischoff, 2005). Among dual-earner couples, wives typically experience higher levels of work-family conflict than husbands, particularly when young children are in the home (Higgins, Duxbury, \& Lee, 1994; Marshall \& Barnett, 1993). It becomes difficult for dual-career couples to adjust to the high level of dual commitment in family and work when they are parents (Becker \& Moen, 1999). For example, 


\section{Dual-Career Couples}

such couples may find it more challenging to take time off from work when the child is sick (Neault \& Pickerell, 2005).

The attempt to balance work life and family life, is likely to create demands, stresses, and frustrations in men's and women's emotional lives and in the style of family relationships (Schulz, Cowan, Cowan, \& Brennan, 2004). According to Brennan, Barnett, and Gareis (2001), a working couple's marital happiness depends on the working time of the female. As women's employment and career is considered as violating the values and norms revolving around the female role, it causes more conflict and less marital happiness (Yogev, 1981). It is found from past studies that spouses' perception about inequality in the division of household labour can undermine marital satisfaction (Yogev \& Brett, 1985; Gjerdingen, McGovern, Bekker, Lundberg, \& Willemsen, 2000). Besides, the role of parenting increases the complicacy in marital life (Holahan \& Gilbert, 1979). This complicacy may even increase among couples when the wife's occupational achievements exceed the husband's (Hiller \& Philliber, 1982). As a result, the divorce rate is increasing among dual-career couples (Henry \& Parthasarathy, 2010).

Dual-career couples have social networks to maintain such as other family members and friends, however there also have time constraints due to their employment (Gorissen, 2009). Such situations may lead to alienation from the family and cause more stress (Lee, 1980; Khan, 2004). The children of such families also become alienated from the extended family and kinship network due to the time pressures encountered by their dual-career parents (Singh \& Singh, 1996).

With all these problems, the stress confronted by dual-career couples is becoming a serious concern in their lifestyle (Kessler \& McRae, 1982; Ross, Mirowsky, \& Huber, 1983). The parenting role (Neault \& Pickerell, 2005) and unequal household division of labor (Yogev \& Brett, 1985) can lead to a great deal of stress among dual-career couples. Research 
Sultana, Tabassum, \& Abdullah

consistently links the stress of dual-career couples with psychological well-being (Lavee, Sharlin, \& Katz, 1996) and mental health (Ross et al., 1983). Moreover, such high levels of stress can lead to burnout (Aryeel, 1993), sleep deprivation (Neault \& Pickerell, 2005), and impaired health (Floderus et al., 2009). The difficulties faced by dual-career couples further leads to diminished job satisfaction and career success (Kossek \& Ozeki, 1998), lower marital quality (Rogers \& May, 2003), and less life satisfaction (Bartley, Judge, \& Judge, 2007). Due to this growing literature and interest in dual-career problems, the current study is initiated with regard to Bangladeshi dual-career couples.

\section{Methodology}

\section{Procedure}

The data was collected in Dhaka, the capital city of Bangladesh, by means of a structured questionnaire. In total, 155 dual-career couples with children were included as participants in this study on a voluntary basis. Of these, questionnaires relating to 143 couples were found to be usable for this research project. Thus, a total number of 286 responses were considered for statistical analysis based on the corresponding husband-and-wife marital relationship. As such, the sample consisted of 143 male and 143 female participants.

\section{Participants}

Among the 286 respondents, $38.9 \%$ of the respondents fell in the age range of $21-30$ years, $41.4 \%$ fell in the $31-40$ range, $16.9 \%$ fell in the $41-50$ range, and the rest $(2.8 \%)$ have an age range of above 50 years. In terms of education, $10.3 \%$ respondents were below the graduate level, $53.9 \%$ were graduates, and $30.3 \%$ were post-graduates. Among all the respondents, $30.6 \%$ were public service holders and the rest, $69.4 \%$, were private service holders. $46.8 \%$ reported having one child, $41.9 \%$ had two children, and the rest $11.1 \%$ had three children. Among the 143 couples, 55 couples were part of a joint family while the rest formed nuclear families. 
Dual-Career Couples

\section{Measures}

A self-constructed structured questionnaire with thirty-four item statements was designed to collect the responses from the dual-career couples. The answer format was a 5point Likert scale ranging from strongly disagree (1) to strongly agree (5). The scale included item statements based on the problems faced by dual-career couples in Bangladesh. A focus group discussion was used prior to the designing of the questionnaire, as a means of an in-depth interview with six dual-career parents. The interviews were focused on the problems related to day-to-day problems of the dual-career couples. The interviews included questions, such as, "What type of problems/challenges do you usually face as a dual-career couple?" Once they answered such questions, more in-depth queries were asked of the couples. In general, all of the interview participants mentioned the problems related to work and family conflict, childcare, household maintenance, marital relationship maintenance, social relationship maintenance, and physical and psychological well-being. Given these responses, the questionnaire included item statements, such as, "The demands of my work interfere with my home family life," "I do not get sufficient time for caring my child/children," "I do not get sufficient time for cooking," I do not have the opportunity to take care of my spouse," "I do not get enough time to attend family/social occasions," and "I feel stressed due to the problems I face as a member of a dual-career family."

\section{Reliability and Validity of Data}

According to Hair, Black, Babin, Anderson and Tatham (2007), validity is the degree to which measures accurately represent what they are supposed to. There are three types of validity: content validity, predictive validity, and construct validity (Siddiqi, 2010). The current study emphasized content validity. Duggirala, Rajendran, and Anantharaman (2008) defined content validity as the assessment of the correspondence between the individual items and concept. Malhotra (2010) termed the content validity as face validity. Sharafi and 
Sultana, Tabassum, \& Abdullah

Shahrokh (2012) mentioned that in the social sciences, content validity can be verified by the professional knowledge of the researchers. A literature review and the assistance of experts can be used for appropriate and relevant measurements for a study (Sharafi \& Shahrokh, 2012). This study concentrated on content validity through the review of literature and adapted instruments which were used in previous studies.

According to Hair et al. (2007), reliability differs from validity in that it relates not to what should be measured, but instead to how it is measured. Thus, reliability is the extent to which a variable or set of variables is consistent in what it is intended to measure (Hair et al. 2007). The current study applied an internal consistency method because multiple items were used for all constructs. The Cronbach alpha value of at least 0.70 was the basis for reliability (Cronbach, 1951) and thus the 0.70 alpha value demonstrated that all attributes were internally consistent (Fujun, Hutchinson, Li, \& Bai, 2007). The Cronbach alpha value for this study was 0.893 which meets the criteria of cut off point. Thus, all the attributes of this study were reliable.

\section{Statistical Tools for Data Analysis}

The responses were analyzed with SPSS. The study is based on the data collected to explore the problems faced by dual-career couples. For this purpose a 5-point 'Likert scale' was used which is a numerical and more specifically, allowed for interval-scaled data. The corresponding probability distribution of this numerical data point was a continuous distribution. However, as the data was informing the opinion through ranking, it is very likely that the parent distribution would not follow a normal pattern. This pre-assumption has been further confirmed by illustration of the Probability-Probability plot (P-P plot) of items. The central view and diversity among the views of the respondents were observed in case of each item individually. The distribution pattern of all the components as a whole expressing all the basic features was observed along with a Box-plot diagram. Then, Principal Component 
Dual-Career Couples

Analysis (PCA) with Varimax rotation was applied to extract the problems faced by the dualcareer couples in Bangladesh.

\section{Results and Discussion}

\section{Principal Component Analysis (PCA)}

This study performed the PCA with Varimax rotation to extract the challenges faced by the dual-career couples in terms of Bangladesh. PCA is used in those instances when the primary concern is to determine the minimum number of factors that would account for maximum variance in the data (Malhotra, 2010). In order to measure the appropriateness of the factor analysis, the Kaiser-Meyer-Olkin (KMO) measure of sampling adequacy was examined. The value of KMO was 0.848 , which was an indication of sampling adequacy (Kaiser, 1970) (see Table 1 below). The measure of sampling adequacy was confirmed as significant from the Bartlett's Test of Sphericity ( $p$-value $<0.01)$.

\section{Table 1: Result for KMO and Bartlett's Test}

\begin{tabular}{|l|l|c|}
\hline \multicolumn{2}{|l|}{ Kaiser-Meyer-Olkin Measure of Sampling Adequacy } & 0.848 \\
\hline Bartlett's Test of Sphericity & Approx. Chi-Square & 3222.404 \\
\cline { 2 - 3 } & Df & 561 \\
\cline { 2 - 3 } & Sig. value & $0.000^{*}$ \\
\hline
\end{tabular}

* Measure of sampling adequacy is significant at 0.01 level.

An examination of Eigenvalues confirmed that nine components were extracted. The extracted nine components could explain as much as $59.967 \%$ of the total variation that was caused by the nine variables. The first component explained the most, about $22.817 \%$, whereas the ninth component explained $3.024 \%$ of the total variation. The remaining variance was explained by other components (see Table 2 below). 
Sultana, Tabassum, \& Abdullah

Table 2: Total variance explained by PCA

\begin{tabular}{|c|c|c|c|c|c|c|}
\hline \multirow{2}{*}{ Component } & \multicolumn{3}{|c|}{ Initial Eigenvalues } & \multicolumn{3}{|c|}{ Rotation Sums of Squared Loadings } \\
\cline { 2 - 7 } & Total & $\begin{array}{c}\text { \% of } \\
\text { Variance }\end{array}$ & Cumulative \% & Total & $\begin{array}{c}\text { \% of } \\
\text { Variance }\end{array}$ & Cumulative \% \\
\hline 1 & 7.758 & 22.817 & 22.817 & 3.155 & 9.280 & 9.280 \\
\hline 2 & 2.869 & 8.438 & 31.255 & 2.867 & 8.434 & 17.714 \\
\hline 3 & 2.115 & 6.221 & 37.476 & 2.666 & 7.841 & 25.555 \\
\hline 4 & 1.610 & 4.734 & 42.211 & 2.405 & 7.072 & 32.627 \\
\hline 5 & 1.489 & 4.379 & 46.590 & 2.328 & 6.848 & 39.475 \\
\hline 6 & 1.238 & 3.641 & 50.231 & 2.200 & 6.472 & 45.946 \\
\hline 7 & 1.183 & 3.479 & 53.710 & 1.834 & 5.393 & 51.340 \\
\hline 8 & 1.099 & 3.233 & 56.943 & 1.656 & 4.872 & 56.212 \\
\hline 9 & 1.028 & 3.024 & 59.967 & 1.277 & 3.756 & 59.967 \\
\hline
\end{tabular}

Extraction Method: Principal Component Analysis.

The principle components were further rotated using Varimax with Kaiser

Normalization algorithm. The result of the rotated component matrix is presented in Table 3 .

Table 3 also shows the $h^{2}$ (communalities) of each variable. It varies from $44.4 \%$ to $76.9 \%$, suggesting the extracted factors were sufficient to account for most of the variations of variables existing in the data. The factor loading those are greater than 0.40 were considered and all the variables were loaded on the nine components. 
Dual-Career Couples

Table 3: Rotated component matrix

\begin{tabular}{|c|c|c|c|c|c|c|c|c|c|c|}
\hline \multirow{2}{*}{ No. } & \multicolumn{9}{|c|}{ Component } & \multirow{2}{*}{$h^{2}$} \\
\hline & 1 & 2 & 3 & 4 & 5 & 6 & 7 & 8 & 9 & \\
\hline Q1 & & & 0.768 & & & & & & & 0.698 \\
\hline $\mathrm{Q} 2$ & & & 0.767 & & & & & & & 0.662 \\
\hline Q3 & & & 0.559 & & & & & & & 0.541 \\
\hline Q4 & & & & & & & 0.479 & & & 0.596 \\
\hline Q5 & & & & & & & 0.562 & & & 0.597 \\
\hline Q6 & & 0.488 & & & & & & & & 0.609 \\
\hline Q7 & & 0.678 & & & & & & & & 0.555 \\
\hline Q8 & & 0.735 & & & & & & & & 0.639 \\
\hline Q9 & & 0.501 & & & & & & & & 0.548 \\
\hline Q10 & & 0.673 & & & & & & & & 0.528 \\
\hline Q11 & 0.729 & & & & & & & & & 0.645 \\
\hline Q12 & 0.710 & & & & & & & & & 0.647 \\
\hline Q13 & 0.556 & & & & & & & & & 0.551 \\
\hline Q14 & 0.675 & & & & & & & & & 0.578 \\
\hline Q15 & & & & & 0.618 & & & & & 0.531 \\
\hline Q16 & & & & & 0.474 & & & & & 0.528 \\
\hline Q17 & & & & & & & & 0.648 & & 0.560 \\
\hline Q18 & & & & & & & & 0.690 & & 0.641 \\
\hline Q19 & & & & & 0.724 & & & & & 0.663 \\
\hline Q20 & & & & & 0.627 & & & & & 0.535 \\
\hline Q21 & & & & & 0.558 & & & & & 0.658 \\
\hline Q22 & & & & 0.475 & & & & & & 0.538 \\
\hline Q23 & & & & 0.472 & & & & & & 0.554 \\
\hline Q24 & & & & 0.586 & & & & & & 0.444 \\
\hline Q25 & & & & 0.551 & & & & & & 0.622 \\
\hline Q26 & & & & 0.655 & & & & & & 0.651 \\
\hline Q27 & & & & & & & 0.717 & & & 0.698 \\
\hline Q28 & & & & & & & 0.500 & & & 0.588 \\
\hline Q29 & & & & & & & & & 0.807 & 0.683 \\
\hline Q30 & & & & & & & & & 0.429 & 0.584 \\
\hline Q31 & & & & & & 0.839 & & & & 0.769 \\
\hline Q32 & & & & & & 0.743 & & & & 0.696 \\
\hline Q33 & & & & & & 0.586 & & & & 0.584 \\
\hline Q34 & & & & & & 0.413 & & & & 0.469 \\
\hline
\end{tabular}

Rotation Method: Varimax with Kaiser Normalization, Rotation converged in 11 iterations.

The questionnaire item statements are indicated with the symbol Q.

\section{Component 1 - Childcare Responsibilities}

It is evident from Table 3 that variables Q11, Q12, Q13, and Q14 formed a group and explained $22.817 \%$ of the total variance. The accumulation of these variables under the first component indicates the existence of a latent relationship among them.

The associated factor loading of the first element means the variable 'lack of sufficient time for childcare' was 0.729 , which implied that it was highly correlated with the first component and could explain about $64.5 \%$ of the variance of dual-career challenges 
caused by this variable. The second variable was 'lack of psychological attachment with children' having factor loading 0.710 , which could explain $64.7 \%$ of the variance caused by the variable. The third and forth variable of this component were 'lack of time for the education of children' and 'lack of opportunity to attend the school/college programs of children,' having factor loading 0.675 and 0.556 respectively, which were able to explain $57.8 \%$ and $55.1 \%$ of variance caused by Q13 and Q14 variable (see Table 4 below). The communalities of the variables were satisfactory and thus ensured that the extracted components are well representatives of the original variables. The variables under component 1 relate to childcare responsibilities of the dual-career parents, which signify lack of sufficient time and opportunity for childcare, lack of psychological attachment with children, lack of time for education of children and time to attend the programs of school or college of children. These four variables were directly related with the taking care of children; that is why they have been classified under this component.

Table 4: Factor loading and communality for each variables of Component 1

\begin{tabular}{|c|l|c|c|}
\hline Variable Number & \multicolumn{1}{|c|}{ Name of the Variable } & Factor Loading & $h^{2}$ \\
\hline Q11 & Lack of sufficient time for childcare & 0.729 & 0.645 \\
\hline Q12 & $\begin{array}{l}\text { Lack of psychological attachment } \\
\text { with children' }\end{array}$ & 0.710 & 0.647 \\
\hline Q14 & $\begin{array}{l}\text { Lack of time for the education of } \\
\text { children }\end{array}$ & 0.675 & 0.578 \\
\hline Q13 & $\begin{array}{l}\text { Lack of opportunity to attend the } \\
\text { school/college programs of children }\end{array}$ & 0.556 & 0.551 \\
\hline
\end{tabular}

\section{Component 2 - Family-to-work Conflict}

The second component was formed with five variables Q6, Q7, Q8, Q9, and Q10 that explained $8.438 \%$ of the total variance. According to Table 5 below, 'lack of opportunity to complete the work for family demand' had the highest factor loading that is 0.735 , which was able to explain about $63.9 \%$ of the variance of dual-career challenges caused by this variable. 


\section{Dual-Career Couples}

The second highest factor loading was 'putting off doing things at work due to family demand' with 0.678 , which could explain $55.5 \%$ of the variance, and the third variable ‘interference of family-related strains in job' had factor loading 0.673 , which could explain $52.8 \%$ variance caused by this variable. The fourth variable of this component 'interference of home life in job responsibilities' could explain $54.8 \%$ of variance with factor loading of 0.501 , and the last variable 'interference of family demand in work related activities' had factor loading 0.488 and could explain $60.9 \%$ of the variance. All the communalities were satisfactory and representatives of original variables. The variables under component 2 relate to the factors of family life that at times hinder the regular activities in the work place; that is why this component is named family to work conflict. The variables include lack of opportunity to complete the work for family demand, putting off doing things at work due to family demand, interference of home life as well as family related strains in job as well as interference of family demand in work related activities. All of these variables indicate the difficulties to perform work in the work place due to the emergence of family related issues.

Table 5: Factor loading and communality for each variables of Component 2

\begin{tabular}{|c|l|c|c|}
\hline Variable Number & \multicolumn{1}{|c|}{ Name of the Variable } & Factor Loading & $h^{2}$ \\
\hline Q8 & $\begin{array}{l}\text { Lack of opportunity to complete the } \\
\text { work for family demand }\end{array}$ & 0.735 & 0.639 \\
\hline Q7 & $\begin{array}{l}\text { Putting off doing things at work due } \\
\text { to family demand }\end{array}$ & 0.678 & 0.555 \\
\hline Q10 & $\begin{array}{l}\text { Interference of family-related strains } \\
\text { in job }\end{array}$ & 0.673 & 0.528 \\
\hline Q9 & $\begin{array}{l}\text { Interference of home life in job } \\
\text { responsibilities }\end{array}$ & 0.501 & 0.548 \\
\hline Q6 & $\begin{array}{l}\text { Interference of family demand in } \\
\text { work related activities }\end{array}$ & 0.488 & 0.609 \\
\hline
\end{tabular}

\section{Component 3 - Work-to-family Conflict}

The third extracted component explained about $6.221 \%$ of the total variance and formed of three variables Q1, Q2, and Q3. The variable 'interference of work demand in 
family life' had the highest factor loading within this component that is 0.768 , which could explain $69.8 \%$ of variance of dual-career challenges caused by the variable Q1. The second variable under this component was 'difficulty in family activities due to the time demand of job' with factor loading 0.767 , which could explain about $66.2 \%$ of the variance caused by the variable. The last variable of this component 'lack of opportunity to complete the family responsibilities due to work demand' could explain $54.1 \%$ variance and had a factor loading of 0.559 (see Table 6 below). The variables under component 3 indicate the work related factors that create obstacles in family life. Variables like interference of work demand in family life, difficulty in family activities due to the time demanded by the job, and lack of opportunity to complete the family responsibilities due to work demand. All signify the problematic situations in which people face difficulties maintaining sound work and family life. That is why this component is entitled work to family conflict.

Table 6: Factor loading and communality for each variables of Component 3

\begin{tabular}{|c|l|c|c|}
\hline Variable Number & \multicolumn{1}{|c|}{ Name of the Variable } & Factor Loading & $h^{2}$ \\
\hline Q1 & $\begin{array}{l}\text { Interference of work demand in } \\
\text { family life }\end{array}$ & 0.768 & 0.698 \\
\hline Q2 & $\begin{array}{l}\text { Difficulty in family activities due to } \\
\text { the time demand of job }\end{array}$ & 0.767 & 0.662 \\
\hline Q3 & $\begin{array}{l}\text { Lack of opportunity to complete the } \\
\text { family responsibilities due to work } \\
\text { demand }\end{array}$ & 0.559 & 0.541 \\
\hline
\end{tabular}

\section{Component 4 - Marital Relationship Maintenance}

The fourth extracted from PCA was formed with five variables, which could explain $4.734 \%$ of the total variance. The variable Q26 that is 'difficulty in terms of maintaining the marital relationship' had the highest factor loading 0.655 , which could explain $65.1 \%$ of the variance under this component of dual-career challenges. The second highest factor loading was found in the variable 'lack of opportunity for meaningful/quality time with spouse,' and 
the third highest factor loading was found in the variable 'interpersonal conflict with spouse.' The factor loading values for these variables were 0.586 and 0.551 , and these variables could explain $44.4 \%$ and $62.2 \%$ of the variance respectively. The fourth variable of this component was 'lack of sufficient time for spouse' with factor loading 0.475 and communality of $53.8 \%$. The last variable of this component was 'lack of opportunity to take care of spouse,' which had a factor loading 0.472 and could explain $55.4 \%$ of variance (see Table 7 below). The variables under this component related to marital issues like difficulty in terms of maintaining the marital relationship, lack of opportunity for quality time with a spouse, interpersonal conflict with spouse, lack of sufficient time as well as lack of opportunity to take care of a spouse. All these factors hinder the difficulty to maintain a sound marital relationship which is the reason this component has been titled marital relationship maintenance.

Table 7: Factor loading and communality for each variables of Component 4

\begin{tabular}{|c|l|c|c|}
\hline Variable Number & \multicolumn{1}{|c|}{ Name of the Variable } & Factor Loading & $h^{2}$ \\
\hline Q26 & $\begin{array}{l}\text { Difficulty in terms of maintaining } \\
\text { the marital relationship }\end{array}$ & 0.655 & 0.651 \\
\hline Q24 & $\begin{array}{l}\text { Lack of opportunity for } \\
\text { meaningful/quality time with spouse }\end{array}$ & 0.586 & 0.444 \\
\hline Q25 & Interpersonal conflict with spouse & 0.551 & 0.622 \\
\hline Q22 & Lack of sufficient time for spouse & 0.475 & 0.538 \\
\hline Q23 & $\begin{array}{l}\text { Lack of opportunity to take care of } \\
\text { spouse }\end{array}$ & 0.472 & 0.554 \\
\hline
\end{tabular}

Component 5 - Dependability on Others in terms of Childcare and Household Responsibilities

The fifth extracted component was formed with five variables; Q15, Q16, Q19, Q20, and Q21. The factor loading and communalities for these variables are represented in Table 8 below. According to Table 8, the first variable of this component was 'dependability on maid/servant for household activities' with the highest factor loading 0.724 and it could explain $66.3 \%$ of the variance caused by component 5 in terms of dual-career challenges. The 
second and third variable of this component were 'dependability on spouse/children/other family members for household activities' and 'dependability on maid/servant for childcare responsibilities' respectively. The factor loading for the second variable was 0.627 and could explain $53.5 \%$ of the variance. The factor loading for the third variable was 0.618 and could explain $53.1 \%$ of the variance. The fourth variable of this component was 'difficulty in terms of maintaining household activities alone,' which had a factor loading of 0.558 and could explain $65.8 \%$ of the variance. The last variable of this component was 'difficulty in terms of childcare responsibilities alone' with a factor loading of 0.474 and communality of $52.8 \%$. Variables under this component are related with dependence on others to perform the household activities and childcare responsibilities. Variables include dependability on a maid or servant for household activities, dependability on spouse or children or other family members for household activities, dependability on a maid or servant for childcare responsibilities and difficulty in terms of maintaining household activities as well as childcare responsibilities alone. All of these indicate the scenario of the dependence on others to perform household activities and carrying out childcare responsibilities, which is the reason this component is named dependability on others in terms of childcare and household responsibilities.

Table 8: Factor loading and communality for each variables of Component 5

\begin{tabular}{|c|l|c|c|}
\hline Variable Number & \multicolumn{1}{|c|}{ Name of the Variable } & Factor Loading & $h^{2}$ \\
\hline Q19 & $\begin{array}{l}\text { Dependability on maid/servant for } \\
\text { household activities }\end{array}$ & 0.724 & 0.663 \\
\hline Q20 & $\begin{array}{l}\text { Dependability on } \\
\text { spouse/children/other family } \\
\text { members for household activities }\end{array}$ & 0.627 & 0.535 \\
\hline Q15 & $\begin{array}{l}\text { Dependability on maid/servant for } \\
\text { hildcare responsibilities }\end{array}$ & 0.618 & 0.531 \\
\hline Q21 & $\begin{array}{l}\text { Difficulty in terms of maintaining } \\
\text { household activities alone }\end{array}$ & 0.558 & 0.658 \\
\hline Q16 & $\begin{array}{l}\text { Difficulty in terms of childcare } \\
\text { responsibilities alone }\end{array}$ & 0.474 & 0.528 \\
\hline
\end{tabular}




\section{Component 6-Personal Well-being}

Table 9 below represents the sixth extracted component found from the PCA. This component could explain $3.641 \%$ of the total variance and was formed with four variables. According to Table 9, the first variable of this component was 'stress due to the problems of in dual-career family,' which had the highest factor loading of 0.839 and it could explain $76.9 \%$ of the variance. 'Exhaustion due to the problems in dual-career family' was the second variable of this component with a factor loading 0.743 and communality of $69.6 \%$. The third variable was 'sadness for fulfilling the life expectations,' which had a factor loading of 0.586 and could explain $58.4 \%$ of the variance. The last variable of component 6 was 'difficulty in terms of physical health' which could explain $46.9 \%$ of the variance and had a factor loading value of 0.413 . Variables under this component included stress due to the problems faced by a dual career family, exhaustion due to the problems in dual career families, sadness in fulfilling life expectations, and difficulty in terms of physical health related to the personal well being of the respondents. These factors altogether point out the condition of the personal feelings of those who were members of dual career families; that is why this component is being named personal well being.

Table 9: Factor loading and communality for each variables of Component 6

\begin{tabular}{|c|l|c|c|}
\hline Variable Number & \multicolumn{1}{|c|}{ Name of the Variable } & Factor Loading & $h^{2}$ \\
\hline Q31 & $\begin{array}{l}\text { Stress due to the problems of in } \\
\text { dual-career family }\end{array}$ & 0.839 & 0.769 \\
\hline Q32 & $\begin{array}{l}\text { Exhaustion due to the problems in } \\
\text { dual-career family }\end{array}$ & 0.743 & 0.696 \\
\hline Q33 & $\begin{array}{l}\text { Sadness for fulfilling the life } \\
\text { expectations }\end{array}$ & 0.586 & 0.584 \\
\hline Q34 & Difficulty in terms of physical health & 0.413 & 0.469 \\
\hline
\end{tabular}


Sultana, Tabassum, \& Abdullah

\section{Component 7 - Family Activity Maintenance}

According to the result of PCA, the seventh extracted component was formed with four variables; Q3, Q4, Q27, and Q28. This component explained 3.479\% of the total variance in terms of dual-career challenges. Table 10 below represents the variances explained by the variables of this component along with factor loading values. The first variable of this component was 'lack of time for family occasions' with the highest factor loading 0.717 which explained $69.8 \%$ of the variance. The second highest factor loading, 0.562 was found in the variable 'change of family-related plans due to work-related duties' and could explain $59.7 \%$ of the variance. The third and fourth variable of component 7 had a factor loading of 0.500 and 0.479 respectively with variance explanations of $58.8 \%$ and $59.6 \%$ respectively. These variables were 'lack of time for parents/in-laws/relatives' and 'changes in family-related plans due to work-related strain'. The variables in this component like lack of time for family occasion, change of family related plans due to work related duties, lack of time for parents or in laws or relatives followed by changes in family related plans due to work related strain indicate the difficulties faced by the respondents maintaining family activities which is the reason this component is phrased as family activity maintenance.

Table 10: Factor loading and communality for each variables of Component 7

\begin{tabular}{|c|l|c|c|}
\hline Variable Number & \multicolumn{1}{|c|}{ Name of the Variable } & Factor Loading & $h^{2}$ \\
\hline Q27 & Lack of time for family occasion & 0.717 & 0.698 \\
\hline Q5 & $\begin{array}{l}\text { Change of family-related plans due } \\
\text { to work-related duties }\end{array}$ & 0.562 & 0.597 \\
\hline Q28 & $\begin{array}{l}\text { Lack of time for parents/in- } \\
\text { laws/relatives }\end{array}$ & 0.500 & 0.588 \\
\hline Q4 & $\begin{array}{l}\text { Changes in family-related plans due } \\
\text { to work-related strain }\end{array}$ & 0.479 & 0.596 \\
\hline
\end{tabular}


Dual-Career Couples

\section{Component 8 - House-keeping Activities}

The eighth extracted component from the PCA was formed with two variables; 'lack of sufficient time for other house-keeping activities' and 'lack of sufficient time for cooking', which could explain $3.233 \%$ of the total variance. The first variable explained $64.1 \%$ of the variance and had a factor loading of 0.690 and the second variable, with a factor loading of 0.648 explained $56 \%$ of the variance (see Table 11 below). The two variables here - lack of sufficient time for cooking and other house-keeping activities directly relate to the problematic issue of having an inadequate amount of time for such activities due to the fact that the majority of time is devoted to job related activities. That is why this component is named house-keeping activities.

Table 11: Factor loading and communality for each variables of Component 8

\begin{tabular}{|c|l|c|c|}
\hline Variable Number & \multicolumn{1}{|c|}{ Name of the Variable } & Factor Loading & $h^{2}$ \\
\hline Q18 & $\begin{array}{l}\text { Lack of sufficient time for other } \\
\text { house-keeping activities }\end{array}$ & 0.690 & 0.641 \\
\hline Q17 & Lack of sufficient time for cooking & 0.648 & 0.560 \\
\hline
\end{tabular}

\section{Component 9 - Social Relationship Maintenance}

The ninth extracted component according to the PCA could explain $3.024 \%$ of the total variance and was formed with two variables. The first variable with the highest factor loading of 0.807 explained $68.3 \%$ of the variance and the second variable with a factor loading of 0.429 explained $58.4 \%$ of the variance. The first variable was 'lack of sufficient time for friends' and the second variable was 'lack of opportunity for social networking' (see Table 12 below). All the communalities were satisfactory and representative of the original variables. Here the variables - lack of sufficient time for friends and lack of opportunity for social networking upholds the scope of maintaining the social relationships of the 
Sultana, Tabassum, \& Abdullah

respondents due to lack of time and this is the reason this component has been named social relationship maintenance.

Table 12: Factor loading and communality for each variables of Component 9

\begin{tabular}{|c|l|c|c|}
\hline Variable Number & \multicolumn{1}{|c|}{ Name of the Variable } & Factor Loading & $h^{2}$ \\
\hline Q29 & Lack of sufficient time for friends & 0.807 & 0.683 \\
\hline Q30 & $\begin{array}{l}\text { Lack of opportunity for social } \\
\text { networking }\end{array}$ & 0.429 & 0.584 \\
\hline
\end{tabular}

\section{Practical Implications}

The study assessed the contribution of various components of dual-career challenges in the city of Dhaka. Different measures and analyses regarding the components can be derived from the study along with the abilities of couple in coping with the challenges regardless of the nature of the job and industry they are employed in. At the same time, the employers of industries can obtain a clearer point of view regarding the nature of the problems and difficulties faced by dual career couples in this study. In fact, employers may formulate their human resource policies to lessen the problems experienced by dual-career parents based on the findings of this current study. If these difficulties are left without consideration, they can significantly reduce job performance, job satisfaction, marital satisfaction, and life satisfaction among dual-career couples. That is why a collaborative effort on the part of both the employers and employees is crucial for fostering a positive work environment in organizations in Bangladesh. In such an environment, dual-career couples will be able to overcome their problems, which in turn will motivate them to put more effort into their work and their family. In addition, the current study can be a valuable source of empirical evidence for practitioners and academics who deal with issues relating to dualcareer couples. 


\section{Limitations and the Direction of Future Research}

The results associated with this study need to be viewed and acknowledged in light of its limitations. First, the data was only collected from the city of Dhaka and as such, the findings cannot be generalized. Therefore, future research should be conducted on a larger scale by considering more dual-career couples from all over Bangladesh to authenticate the findings of this study. Second, to determine the sample size of respondents, statistically accepted techniques should be utilized. It was not possible for the current researchers to use many of the statistically acceptable techniques as such a procedure would require a significant amount of monetary and non-monetary resources. Third, the inferences drawn from this study are limited by self-reporting data and cross-sectional characteristics of the data.

\section{Conclusion}

The study was conducted to investigate the challenges of dual career couple in Dhaka city. The study explored this issue because of the dual responsibilities involved on the part of working couples and their vulnerability to such problems as work-family conflict, familywork conflict, childcare responsibilities, marital relationship maintenance, dependency on others in terms of childcare and household responsibilities, personal well-being, family activity maintenance, housekeeping activities, and social relationship maintenance. Difficulties associated with these concepts can lead to job-life dissatisfaction (Perrewe \& Hochwarter, 1999) and decrease martial satisfaction (Perrone \& Worthington, 2001) among dual-career couples. As a result, they may also influence life satisfaction of dual-career members (Bonebright, Clay, \& Ankenmann, 2000). To minimize these complexities, it is suggested that the employers of dual-career couples should revise their organizational policies to be family-friendly as this change would increase employee and organizational 
Sultana, Tabassum, \& Abdullah

performance. As the numbers of dual-career problems increase day by day, family counselors and dual-career couples together can discover coping strategies that will ultimately ensure a happy work-life, happy family life and enjoyable life for dual-career couples. 
Dual-Career Couples

\section{References}

Aldous, J. (1982). Two paychecks: Life in dual-earner families. Beverly Hills: Sage Publications.

Anderson, E. A., \& Spruill, J. W. (1993) The Dual-Career Commuter Family: A Lifestyle on the Move. Marriage \& Family Review, 19(1/2), 131-147.

Arbeau, K. (2001). Counselling and the dual career couple. Psynopsis: Canada's Psychology Newspaper, 23(1), 22.

Aryeel, S. (1993). Dual-Earner Couples in Singapore: An Examination of Work and Nonwork Sources of Their Experienced Burnout. Human Relations, 46(12), 14411468 .

Bartley, S. J., Judge, W., \& Judge, S. (2007). Antecedents of Marital Happiness and Career Satisfaction: An Empirical Study of Dual-Career Managers. Journal of Business and Public Affairs, 1(1).

Baruch, G., Barnett, R., \& Rivers, C. (1983). Lifeprints. New York: McGraw Hill.

Becker, P. E., \& Moen, P. (1999). Scaling back: Dual-earner couples' work-family strategies. Journal of Marriage and the Family, 61, 995-1007.

Bonebright, C. A., Clay, D. L., \& Ankenmann, R. D. (2000). The relationship of workaholism with work-life conflict, life satisfaction, and purpose in life. Journal of Counseling Psychology, 47, 469-477.

Brennan, R. T., Barnett, R. C., \& Gareis, K. C. (2001). When she earns more than he does: A longitudinal study of dual-earner couples. Journal of Marriage \& the Family, 63, 168182.

Coltrane, S. (2000). Research on household labor: Modeling and measuring the social embeddedness of routine family work. Journal of Marriage and Family, 62, 12081233.

Cronbach, L. J. (1951). Coefficient alpha and the internal structure of tests. Psychometrika, 16(3), 297-334.

Crouter, A. C., \& Manke, B. (1997). Development of a Typology of Dual-Earner Families: A Window into Differences between and within Families in Relationships, Roles, and Activities. Journal of Family Psychology, 11, 62-75.

Dribe, M., \& Stanfors, M. (2010). Family life in power couples: Continued childbearing and union stability among the educational elite in Sweden, 1991-2005. Demographic Research, 23. Retrieved from http://www.demographicresearch.org/Volumes/Vol23/ $30 /$ 
Duggirala, M., Rajendran, C., \& Anantharaman, R.N. (2008). Patient-perceived dimensions of total quality service in healthcare. Benchmarking: An International Journal, 15(5), $560-583$.

Duxbury, L., \& Higgins, C. (1991). Gender Differences in Work-Family Conflict. Journal of Applied Psychology, 76, 60-74.

Duxbury, L., \& Higgins, C. (2003). Work-life conflict in Canada in the new millennium: A status report (Final Report). Retrieved from http://www.hcsc.gc.ca/pphbdgspsp/ publicat/work-travail/report2/.

Edwards, J., \& Rothbard, N. 2000, Mechanisms Linking Work and Family: Clarifying The Relationship between Work and Family Constructs, Academy of Management Review, 25(1), 178-199.

Elloy, D.F., \& Smith, C. R. (2003). Patterns of Stress, Work-Family Conflict, Role Conflict, Role Ambiguity and Overload Among Dual-Career and Single-Career Couples: An Australian Study. Cross Cultural Management, 10 (1), 55-66.

Floderus B, Hagman M, Aronsson G, Marklund S, Wikman A. (2009, October). Work status, work hours and health in women with and without children. Occupational \& Environmental Medicine, 66(10), 704-10.

Friedan, B. (1963). The feminine mystique. New York: Norton.

Frone, M.R., Russell, M., \& Cooper, M.L. (1992). Antecedents and outcomes of work-family conflict: Testing a model of the work-family interface. Journal of Applied Psychology, 77(1), 65-78.

Fujun, L., Hutchinson, J., Li, D., \& Bai, C. (2007). An empirical assessment and application of SERVQUAL in mainland China's mobile communications industry. The International Journal of Quality \& Reliability Management, 24(3), 244-262.

Galinsky, E., Bond, T., \& Friedman, D. E. (1996). The role of employers in addressing the needs of employed parents. Journal of Social Issues, 52, 111-136.

Gjerdingen, D., McGovern, P., Bekker, M., Lundberg, U., \& Willemsen, T. (2003). Women's work roles and their impact on health, well-being, and career: comparisons between the United States, Sweden, and The Netherlands. Women Health, 31(4), 1-20.

Green, D.H., \& Zenisek, T.J. (1983) Dual Career Couples: Individual and Organizational Implications. Journal of Business Ethics, 2, 171-184.

Greenhaus, J., \& Beutell, N. (1985). Sources of conflict between work and family roles. Academy of Management Review, 10, 76-88.

Hair, J.F., Black, W.C., Babin, B.J., Anderson, R.E., \& Tatham, R.L. (2006). Multivariate Data Analysis. (6 ${ }^{\text {th }}$ ed.). Upper Saddle River, NJ: Pearson Education. 
Hall, F.S., \& Hall, D.T. (1979). The two-career couple. Reading, MA: Addison-Wesley Publishing Company.

Hall, D.T., \& Hall, F.S. (1980). Stress and the dual career couple. In C.L. Cooper \& R. Payne (Eds.), Current concerns in occupational stress. New York: John Wiley.

Henry, J., \& Parthasarathy, R. (2010). The family and work connect: A case for relationshipfocused family life education. Indian Journal of Occupational and Environmental Medicine, 14(1).

Hester, S.B., \& Dickerson, K.G. (1984). Serving Dual-Career Families: Problem or Opportunity? Journal of Extension, 22(4).

Higgins, C.A., \& Duxbury, L.E. (1992). Work-family conflict: A comparison of dual-career and traditional-career men. Journal of Organizational Behavior, 13(4), 389-411.

Higgins, C. A. Duxbury, L. E., Lee, C., \& Mills S. (1994). An examination of work-time and work-location flexibility. The Journal of Public Sector Management, 23, 29-37.

Higgins, C., Duxbury, L., \& Lee, C. (1994). Impact of life-cycle stage and gender on the ability to balance work and family responsibilities. Family Relations, 43, 144-150.

Hiller, D.V., \& Philliber, W. W. (February, 1982). Predicting Marital and Career Success among Dual-Worker Couples. Journal of Marriage and Family, 44(1), 53-62.

Holahan, C. K., \& Gilbert, L. A. (1979). Conflict between major life roles: The women and men in dual-career couples. Human Relations, 32, 451-467.

Kaiser, H.F. (1970). A second generation little jiffy. Pschometrika, 35, 401-415.

Kessler, R. C., \& McRae, J. A., Jr. (1982). The effect of wives' employment on the mental health of married men and women. American Sociological Review, 47, 217-227

Khan, L. T. (2004, March 15). Marital instability in Dhaka, Bangladesh with special reference to dual-earner couples. Retrieved from http://www.lib.uchicago.edu/e/su/ southasia/Lubna.html.

King, J. J. (2005). Gender ideology: impact on dual-career couples' role strain, marital satisfaction, and life satisfaction. A Dissertation for Doctor of Philosophy. Texas A\&M University.

Kossek, E., \& Ozeki, C. (1998). Work-family conflict, policies, and the job-life satisfaction relationship: A review and direction for organization behavior-human resources research. Journal of Applied Psychology, 83(2), 139-150.

Lavee, Y., Sharlin, S., \& Katz, R. (1996). The effect of parenting stress on marital quality: an integrated mother-father model. Journal of Family Issues, 17, 114-135. 
Lee, N. (1980). The dual-career couple: benefits and pitfalls. Management Review, 70(2), 4652.

Lindfors, P., Berntsson, L., \& Lundberg, U. (2006). Total workload as related to psychological well-being and symptoms in full-time employed female and male white-collar workers. International Journal of Behavioral Medicine, 13(2), 131-137.

Malhotra, N. (2010). Marketing Research: An Applied Orientation. $\left(6^{\text {th }}\right.$ Ed.). New Delhi: Prentice Hall.

Marshall, N.L., \& Barnett, R.C. (1993). Work-family strains and gains among two-earner couples. Journal of Community Psychology, 21, 64-78.

Neault, R. A., \& Pickerell, D. A. (2005). Dual-Career Couples: The Juggling Act. Canadian Journal of Counselling / Revue canadienne de counseling. 39(3), 187-198.

O’Laughlin, E. M., \& Bischoff, L. G. (2005). Balancing Parenthood and Academia: Work/Family Stress as Influenced by Gender and Tenure Status. Journal of Family Issues, 26, 79-106.

Perrewe, P. L., \& Hochwarter, W. A. (1999). Value attainment: An explanation for the negative effects of work-family conflict and job and life satisfaction. Journal of Occupational Health Psychology, 4, 318-326.

Perrone, K. M., \& Worthington, E. L. (2001). Factors influencing ratings of marital quality by individuals within dual-career marriages: A conceptual model. Journal of Counseling Psychology, 48, 3-9.

Pleck, J. (1977). The work family role system. Social Problems, 24, 417-427.

Russell, G. (1986). Primary care-taking and role-sharing fathers. In M. Lamb (Ed.), The father's role (pp. 29-57). New York: Wiley.

Rapoport, R., \& Rapoport, R.N. (1969). The Dual-Career Family: A Variant Pattern and Social Change. Human Relations, 22(1), 3-30.

Rapoport, R., \& Rapoport, R. (1971). Dual Career Families. London: Penguin Books.

Rapoport, R., \& Rapoport, R. (1976). Dual-career families re-examined. London: Martin Robertson and Co., Ltd.

Roehling, P. V., Moen, P., \& Batt, R. (2003). When work spills over into the home and home spills over into work. In P. Moen (Ed.), It's about time: Couples and careers. Ithaca, NY: Cornell University Press.

Roehling, P.V., \& Moen, P. (2003). Dual-earner couples. Sloan Work and Family Research Network Resources for Teaching: Work and Family Encyclopedia. Retrieved from http://www.bc.edu/bc_org/avp/wfnetwork/rft/wfpedia/index.html. 
Rogers, S. J., \& May, D. C. (2003). Spillover between marital quality and job satisfaction: Long-term patterns and gender differences. Journal of Marriage and the Family, 65(2): 482-496.

Ross, C. E., Mirowsky, J., \& Huber, J. (1983). Dividing work, sharing work, and in-between: Marriage patterns and depression. American Sociological Review, 48, 809-823.

Schulz, M. S., Cowan, P. A., Cowan, C. P., \& Brennan, R.T. (2004). Coming home upset: Gender, marital satisfaction, and the daily spillover of workday experience into couple interactions. Journal of Family Psychology, 18(1), 250-263.

Sharafi, T., \& Shahrokh, Z.D. (2012). The relationship between family-to-work conflict of employee and co-workers' turnover intention. Management Science Letters, 2, 1-10.

Siddiqi, K.O. (2010). Interrelations between service quality attributes, customer satisfaction and customer loyalty in the retail banking sector in Bangladesh. International Trade \& Academic Research Conference (ITARC) - London 2010.

Singh, L.B., Singh, A.K. (1996). Alienation: A symptomatic reaction of educated employed youth in India. International Journal of Psychology. 31, 101-110.

Smith, C.R. (1992). Dual Careers, Dual Loyalties. Asian Pacific Journal of Human Resources, 30(4), 19-30.

Thompson, L. (1991). Family work: Women's sense of fairness. Journal of Family Issues, 12, 81-196.

Wilkie, J, R. (1991). The decline in the men's labor force participation and income and the changing structure of family economic support. Journal of Marriage and Family, 53,113-122.

Yogev, S. (1981). Do Professional Women Have Egalitarian Marital Relationship? Journal of Marriage and the Family, 43, 865-871.

Yogev, S. (1983), Judging the Professional Woman: Changing Research, Changing Values. Psychology of Women Quarterly, 7, 219-234.

Yogev, S., \& Brett, J. (1985). Perceptions of the Division of Housework and Child Care and Marital Satisfaction. Journal of Marriage and Family, 47(3), 609-618. 